Article

\title{
"He Who Enters the Bath-House Utters Two Blessings": On the Evolvement and Decline of an Ancient Jewish Prayer
}

\author{
Abraham Ofir Shemesh \\ Israel Heritage Department, Ariel University, Kiryat hamadda P.O.B. 3, Ariel 40700, Israel; avi0603@013.net.il
}

Received: 10 August 2017; Accepted: 12 October 2017; Published: 16 October 2017

\begin{abstract}
One of the improvements introduced by the Romans was the public bath-house. This article discusses the formation of Jewish prayers, which were composed during the early rabbinic period, following the dangers of the public baths. Sages from late antiquity published two prayers: Before entering to the bathhouse, the bather has to pray for his safety, and after leaving the bath-house he has to thank G-d for not having suffered harm. The dangers of the bathhouse were deemed to include: Weakness, fainting or dehydration due to the heat of the bathhouse; Legs injury of the bathers due to the heat of the warm floor; Dental damage; Sliding on the wet floor; Fear of death due to collapse of the hypocaust. Due to changes in the bath-house in the modern era; these prayers lost their relevance up to a point; or at any rate; they were no longer prescribed or recorded in practice. Bathhouse heaters were no longer located in the hypocaust; and were rather only located close to the wall of the upper room. Hence; falling into the hot lower space was irrelevant. Following the introduction of domestic baths; these prayers have completely vanished.
\end{abstract}

Keywords: ancient prayer; bath-house; Talmudic literature; hypocaust; caldarium; dangers of bath-house; Jewish halakha; Yehuda Hanassi; Tractate Derech Eretz; Kala Rabati

\section{Introduction}

Evidence of public baths in Eretz Israel exists from as early as the Hellenistic period (Gichon 1978). In the Roman period, bath-houses were one of the material improvements introduced by the Romans in Italy and the provinces. The development and design of bath-houses in the Classical period was made possible by the installation of elaborate aqueducts that facilitated the flow of fresh and drinkable water to the cities. Thus, the bath-houses became a distinct mark of the Roman Empire, as did the public fountains (Nimpheon) and aqueducts (Tsafrir 1988, pp. 54-57). Public bathing facilities in the Roman period and later consisted of built bath complexes, which included baths, heating facilities, and sometimes swimming pools. A range of other activities took place at the bath-houses as well, such as immersion in cold, warm, and hot water, sweating, massages, rubbing the body with scented oil, and also exercise. Hence, the baths served not only for purposes of hygiene rather also as a place of entertainment and social recreation (Gichon 1978; Carcopino 1978, pp. 227-86; Grimal 1983, pp. 68-72; Tsafrir 1988, pp. 105-14; Sperber 1998).

The introduction of baths in Roman territory was an important improvement in the daily routine of the empire's inhabitants. For the Jews, use of the baths generated a list of problems occasioned by their faith and culture. The Mishna and Talmud literature ( 2 th-5th centuries C.E.) mentions various traditions that assess the contribution of Roman building enterprises, including the bath-houses, to the development of Eretz Israel (Babylonian Talmud, Sabbath 33b; Avoda Zara 2b). From a religious-halakhic perspective, the bath-house was the cause of several deliberations among the Jews: 
A. Idolatry-the dominant cultural and design-aesthetic tone in the Roman bath-houses was pagan. The presence of sculptures personifying gods and emperors in the baths raised questions concerning the prohibition against sculptures and masks (Mishnah, Avoda Zara 1:7, 3:4; Eliav 2004; Friedheim 2002). Notably, however, despite the foreign-pagan atmosphere and issues of immodesty, to which the Jews objected (see below), they did not avoid the baths, and this includes Jewish sages (Eliav 1995).

B. Questions related to the Sabbaths and Jewish festivals, such as bathing in a bath-house owned by a Jew or non-Jew on the Sabbath (Mishnah, Machshirin 2:5; Babylonian Talmud, Sabbath 40b).

C. Legal questions-ownership laws dealing with the sale of a private bath-house owned by affluent people (Mishnah, Baba Batra 4:6; Babylonian Talmud, ibid., 67b; Tosefta, ibid., 3:3; Lieberman 1955, p. 139).

D. Questions about whether the bath-house, as an unclean place, requires a mezuzah (Simon 1878) (Yalkut Shimoni 1878; Parashat va-Etchanan, 844).

E. The question of whether ritual baths built within bath-houses, usually in the cold water pool within the frigidarium, were considered valid in accordance with Jewish law (Reich 1988; Grossberg 2001, 2007).

This paper deals with the evolvement of a prayer introduced by Jewish sages as a result of the hazards involved in use of the bath-houses. I shall discuss the reasons for the prayer's introduction, based on the ancient material circumstances, the contents of the prayer, its various versions, and its evolvement over the generations. The current study shows that the bath-house prayer was relevant in the reality of ancient times, while the material changes and transformations that occurred in bathing facilities in modern times led to its complete elimination and, accordingly, it is no longer utilized in Jewish religious practices.

\section{Bath-House Prayer in the Mishna and Talmud}

\subsection{Bath-House Prayers in the Tannaitic Literature}

The bath-house prayer first appeared in Eretz Israel in the Mishna era. According to Ronny Reich (1988), hot baths were first introduced in Eretz Israel in the mid-second century BC. Although the Tannaitic literature was only redacted later (second century CE.), it appears to reflect the ancient bath-house reality in this expanse.

The Mishna codex mentions only the prayer for entering a city (Berakhot 9:3). The Tosefta has a bath-house prayer, beside the city prayer:

[A person] who enters into a bath-house [should] pray two [prayers], one as he enters [the bath house] and one as he exits [the bath house]. As he enters [the bath house] what does he says? May it be your will, Lord my God that you will bring me in peace and you will take me out in peace, and may there not happen with me a disaster. But if a disaster was happened [in Erfurt manuscript and first press: "will happen"] to me may my death be a forgiveness for all of my sins. And save me from this and anything similar to it in the future. [If] he exited in peace he says: I thank You [God] that you took me out in peace. So may it be your will that you will take me to my home in peace.

(Tosefta, Berakhot 6:17; Lieberman 1955, pp. 37-38)

Two prayers are mentioned in the Tosefta: one is recited before entering the bath-house, and the second after leaving. The preliminary prayer is mainly a plea for mercy, asking that the bather not be harmed while at the bath-house. The bather is aware of the possibility that some mishap or accident might prove fatal, and thus includes in the prayer a form of "confession", so that if he dies while bathing his death will atone for his sins. In fact, the Tosefta is the only version that includes a confession in anticipation of possible death. 
In contrast to the preliminary prayer, the post-bathing prayer is a prayer of thanksgiving that nothing bad happened to the bather and that he left the bath-house safely. The bather not only gives thanks for the past, rather also utilizes the departure prayer to request future deliverance from other grave harms that he might encounter in daily life. The Tosefta's version that we have before us does not list the mishaps or hazards involved in visiting a bath-house, and it may be assumed that the person saying the prayer, who was familiar with the bath-house environment, was cognizant of these.

Tractate Kala Rabati 9: 13 (Higger 1936, p. 337) has a different version than the Tosefta:

[One who is about to enter the bath-house] blesses: May it be Thy will O Lord, my God, that you will save me from this [danger], and from similar dangers in the future. And when he leaves he says: I give thanks to you, Master of the Universe, for saving me from sink of the water and the burning fire. May it be Thy will O Lord, my God, that you will save me from similar danger in the future.

While according to the Tosefta, the plea for future deliverance is recited upon entering the bath-house, in Kala Rabati it is recited both when entering and when leaving. The reason for the repetition is not clear, all the more so as supplications regarding the future are suitable primarily only if the bathers managed to leave the bath-house without mishap. Interestingly, the wording of the prayer appears in Kala Rabati fortuitously. The redactor of the tractate (Higger 1936, p. 336) presents the order of operations to be performed by bathers when entering the bath-house after reciting the prayer, i.e., taking off one's robe, untying the sash, removing the hat, etc. The redactor asks why the wording of the bath-house prayer was not stated, and then brings the words of the prayer for entering and leaving. It is possible that the question was presented in rejection of the assumption that this is an optional prayer, and therefore he answers that the prayers themselves were not presented because the tractate deals with good manners and not with the laws of blessings. The most conspicuous element in the version brought in Kala Rabati is the risk of "water sinking" (shki'at mayim), with its vague meaning. This expression appears in no other Talmudic text and we shall discuss its meaning below.

A third version is brought in Tractate Derech Eretz, Perek ha-Nichnas, halakha 1 (Higger 1935, pp. 295-96):

One who is about to enter the bath-house says: May it be Thy will O Lord, my God, to cause me to enter it, to leave it, and to return from it in peace. Save me from its dangers, and from similar dangers in the future.

The wording in Tractate Derech Eretz, which is shorter than the two versions mentioned, is concise and matter-of-fact and does not go into the hazards of bathing. Unlike the Tosefta and Tractate Kala Rabati, it contains only one prayer, recited before entering the bath-house, with no thanksgiving for leaving safely after bathing. In contrast, it encompasses a plea for future deliverance, such that this element is common to all three versions. The short version in Tractate Derech Eretz may have preceded the other versions and may reflect an early stage of formation. Similar to the explanation in Kala Rabati, here too the redactor may have focused on issues related to good manners rather than on the prayer, and thus the short version.

\subsection{The Bath-House Prayer in the Talmuds}

The bath-house prayer, relevant for post-Tannaitic generations as well, was mentioned in both Talmuds, the Jerusalem Talmud and the Babylonian Talmud. I shall quote the two versions and compare them:

Jerusalem Talmud 9:4, Berakhot 14b:

One who enters a bath-house recites two prayers, one when he enters and one when he leaves. When he enters he says "May it be your will, Lord my God, that you save me from the burning fire, and from injury by the steam, and from the collapse. And may nothing occur to endanger my life. But if something happens, may my death atone for all my sins. 
And save me from this and similar dangers in times to come". And when he leaves he says "I give thanks to you, Lord my God, for saving me from the fire".

Babylonian Talmud, Berakhot 60a:

Our Rabbis taught: On entering a bath-house one should say: 'May it be Thy will O Lord, my God, to deliver me from this and from the like of this, and let no humiliation or iniquity befall me; and if I do fall into any perversity or iniquity, may my death be an atonement for all my iniquities' [ ... ] On leaving the bath-house what does he say? R. Aha said: 'I give thanks unto Thee, O Lord, my God, that Thou hast delivered me from the fire'.

(On the Version's changes see Rabinovitch 1867, p. 343)

In the course of the sugya, the Babylonian Talmud brings a tradition in the name of Resh Lakish, one of the greatest Eretz Israel amoraim of the second generation, whereby calamities that might occur in the bath-house should not be mentioned in the prayer, so as not to arouse the evil eye. The sages, however, were not concerned of this and it is interesting that the Jerusalem Talmud does not refer to this belief at all.

Both Talmuds mention a prayer for entering and leaving the bath-house, indicating that in the time of the amoraim two prayers were already customary. In the Jerusalem Talmud, the prayer for leaving is not attributed to any specific sage. In the Babylonian Talmud, however, it is brought in the name of Rav Aha, an Eretz Israel sage of the fourth generation. Both Talmuds mention only thanksgiving for deliverance from fire, and it appears that the redactors of the two Talmuds did not have before them the last part of the Tosefta's version: "[If] he exited in peace he says: I thank You [God] that you took me out in peace. So may it be your will that you will take me to my home in peace".

It is certainly possible to accept Marx's assumption that the prayer for leaving the bath-house was formulated or became customary among bathers at a later stage, for two reasons: first of all, because it is cited in the name of a later sage, and secondly, because the introductory wording of the blessing for leaving is presented in Aramaic (ki nafiq). It is not impossible that the Babylonian sugya was initially redacted close to Rav Aha's time, i.e., in the fourth generation or slightly earlier (Marx 2007).

Saul Lieberman commented, and justly so, that according to the Babylonian Talmud's version the prayer for deliverance from the hazards of the bath-house appears before the confession. In contrast, in the Tosefta the plea for deliverance is mentioned after the request for atonement in case of death, a less logical order. In his opinion, the formulators of the prayer in the Tosefta did not wish to mention a measure of calamity at the end of the prayer and thus preferred to end with an anticipation of good (Lieberman 2000, Berakhot, p. 119).

The versions brought by the Talmuds enumerate several potential hazards that exist at the bath-house. The Babylonian Talmud states, in its prayer for leaving the bath-house, only the fire hazard. In the Jerusalem Talmud's prayer, in contrast, three hazards are stressed: "burning by fire" (srefat esh), "hot water hazard" (heizeq ha-hamin), and "collapse" (mapolet). In order to understand these hazards and others that endangered bathers at the baths, we shall begin by providing a general description of the ancient bath-house.

\subsection{The Bath-House - The Structure and the Functions of Its Rooms}

Beginning from the time of Caesar Augustus (1st century BC.), every bath-house had three main units: (1) The tepidarium (warm room) - The tepidarium was a warm (tepidus) and pleasant bathroom, which heated by a hypocaust or underfloor heating system. It was decorated with richest marbles and mosaics; (2) The caldarium or cella caldaria (hot room) - was a very hot and steamy room. Beside the sodatorium (see below), it was the hottest room in the regular sequence of bathing rooms; (3) The frigidarium (cool room)-The frigidarium was usually located on the northern side of the baths. Generally, the frigidarium includes a small pool of cold water or sometimes a large swimming pool. Public bath-houses usually also had an apodyterium (changing rooms). This room was the primary 
entry in the public baths, composed of a large changing room with cubicles or shelves where citizens could store clothing and other belongings while bathing. There was often also a special room for dry sweating (sodatorium or laconicum), which is the highest degree of sweating-with no immersion in hot water or washing one's face (Gichon 1978; Tsafrir 1988, p. 106).

The caldarium had various basins-a sink for washing one's hands and face in cold or hot water (labrum (and a hot bath with room for sitting (alveus). In the caldarium, the floor was heated with a hypocaust, and the walls were often heated as well. The hypocaust (hypocaustum) was an under-floor space (suspensura), whose ceiling was usually (but not always) supported by a system of stone pillars, where hot air was circulated. In other words, the ceiling of the hypocaust was the floor of the caldarium. The heating room (praefurnium) that served to heat the hypocaust and the water pools included a furnace (formax), a system of pipes and ducts to deliver and drain the water, and pools or vats in which the water was heated. The furnace itself was placed on the side of the hypocaust or underneath it. The idea was for the furnace to be as close as possible to the hypocaust in order to better heat the underlying space (Smith and Anthon 1843, p. 151; Gichon 1978; Tsafrir 1988, p. 106).

\subsection{The Dangers Inherent in Bathing in Ancient Bath-Houses}

The Talmuds included in the prayer the main hazards involved in visiting the baths (fire hazards, hot water, and collapse). Nevertheless, it is clear that in practice bathing in a bath-house involved other risks as well, and some were indeed documented in other contexts in the literature of the period. The impression is that the Talmuds stressed those dangers that entailed a risk of death or grave injury, and their purpose seems to have been to focus on the more critical problems.

The hazards of the bath-house are also mentioned in classical literature. Roman physicians were aware of the health risks associated with spending time at the baths, for example, the transition between rooms with different temperatures. Some people were accustomed to entering the cold water before the warm, while others began with the warm and ended with the cold, with the order of bathing, sweating, washing, and swimming changing accordingly (Gichon 1978).

Another hazard is associated with metaphysical elements. In the Roman world there was a common belief that demons and ghouls are present in the baths and might harm human beings (Bonner 1932, pp. 203-8; Dunbabin 1989, pp. 36-39). Many gods were deemed in charge of the public baths in the Roman Period. The utilization of gods for the purpose of supervising and protecting the bathers indicates how the Romans handled the risks inherent in the bath-house. For example, the god of the baths (Genius thermarum) was in charge of the bathers' well-being and peace (Nielsen 1990, p. 146). Several dedications found in bath-houses from the time of the Roman Empire indicate the popular cult of the Roman goddess of fortune associated with the baths, Fortuna balnearis, who was responsible for protecting the bathers (Nielsen 1990, p. 134; Friedheim 2002, pp. 9-11).

The potential dangers that lie in wait for the bathers can be categorized in several ways. One division is into the dangers associated with the bath-house itself, i.e., the consequences of activity on the hot floor, and the dangers associated with uncontrollable events, such as slipping, breaking vessels, or improper behavior by the bathers. The second division is into health risks that are not life endangering and grave accidents and mishaps that might be fatal for the bather. The division into dangerous and less dangerous hazards is of course not absolute, as relatively slight mishaps might develop into fatal ones (A short discussion on the bathes dangers see Hadar 1995, p. 107; Eliav 1995, pp. 33-34; Sperber 1998, pp. 57-58). The gravest danger for the bathers was death. This concern is evident from the Tosefta Miqvaot 5:7 (Zuckermandel 1937, p. 657), which discusses the halakhic implications of a dead body in the bath-house, as affecting issues of purity and impurity. 


\subsubsection{Health Hazards}

Lengthy Exposure to Heat in the Bath-House-Weakness, Risk of Dehydration, and Fainting

Dehydration as a result of fluid loss or fainting due to the heat in the bath-house was one of the major hazards involved in remaining for a long stretch of time. Consequently, contemporary medical literature provided detailed instructions of how to conduct oneself at the baths.

Bathers were exposed to a real health hazard in the dry sweating room (sodatorium) or the caldarium, as these were very hot. Hence, the sages instructed that bathing in hot water should be done sparingly and that visits to the bath-house should always take place in the morning (Kala Rabati 9:11, Higger 1936, p. 336). This recommended time of day may be because the weather is more temperate in the morning and there is no concern that the bather will leave the heat of the bath-house for the heat outside. The sages objected to sick people visiting the baths. A rabbinical tradition included the bath-house among the ten elements that intensify illnesses. This medical statement was based on the fact that the extreme heat might weaken the sick person or enhance his initially high body temperature (Berakhot 57b).

Going to the bath-house was perceived as an activity that requires physical effort, and for this reason the recommendation was to avoid activities that demand extra effort after bathing (Derech Eretz, Perek ha-Yotze, halakha 2, Higger 1935, p. 307). Some sources suggest that the bathers sit on the floor of the bath-house rather than standing (Eisenstein 1915, p. 162). This is not in order to proper utilize the heat, rather apparently for safety reasons. Sweating in a vertical position was perceived as leading to "forgetting one's studies", and this instruction as well was associated with the effort and confused senses resulting from the heat of the bath-house. This may be the reason for the statement of the amora R. Yehoshua ben Levi that one does not have to stand while reciting the bath-house prayer (Jerusalem Talmud, Berakhot 9:4, 14b).

According to some traditions, bathers would enter the bath-house with their head wrapped in cloth, in order to prevent the heat from coming into direct contact with the head (Ben Meir 1886, Baba Batra 67b). The Tannaitic halakha whereby right of way should be given to those leaving the bath-house rather than to those entering is also associated with limiting one's stay in the hot environment, and with the understanding that the person leaving might be at risk if he is delayed (Derech Eretz, Perek ha-Nichnas, halakha 2, Higger 1935, p. 301; Jerusalem Talmud, Baba Kama 3:5, 3d). In my opinion, this halakha is relevant for the type of bath-house designed as a row of connected rooms, where the bather would return the way he entered. In this configuration, the caldarium was the last in line, so when finished the bather would retrace his steps and encounter those entering from the tepidarium or the frigidarium (Tsafrir 1988, pp. 106-7). The prohibition against entering the hot bath-house before the afternoon prayer was also associated with the dangers posed by this environment (Mishnah, Sabbath 1:2). The explanation given in the Talmud (ibid., 9b) was that the sages were concerned that the bather would faint or not feel well due to the extreme heat in the bath-house, and thus would avoid praying.

In order to refresh himself, the bather was advised to drink after bathing. The beverage was called a "cup of peace" because it helped maintain the bather's peace and health (Nedarim 38b). According to the Talmudic tradition brought in Avoda Zara 30a, after leaving the bath-house it was customary to drink alontit, a beverage made of "old wine and clear water and persimmon", i.e., a mixture of wine, clear water, and balsam fragrance (Commiphora gileadensis), whose good scent appears to have revived the bather (Goor 1966). According to another tradition (Sabbath 41a), bathers would drink hot water after the hot bath, probably because they believed that drinking a hot beverage enhances sweating and cools the body.

\section{Burns to the bathers' feet}

Standing on the floor of the caldarium or in the sweating room could cause burns to the feet. This might be associated with the general inability to regulate the temperature of the bath-house in 
general and of the floors in particular. The ancients solved this problem in two ways. The first was by cooling the torrid floor and walls with water. The liquids would evaporate and create a sauna, but prevented unbearable heat and burns to the bathers' feet (Tsafrir 1988, p. 106). Another way was by using wooden boards (Mishnah, Baba Batra 4:6; Sabbath 40a). Wood, as we know, is a heat-resistant material, so the results were probably very positive.

The exegetic and research literature suggests other purposes of these slats: A. To keep the bathers' feet clean (Ben Meir 1886, Baba Batra 67b); B. To prevent slipping on the marble surface; C. To prevent the feet from becoming cold when standing on the frigidarium's marble, stone, or mosaic floor (Preuss [1911] 2004, p. 535). According to the Jerusalem Talmud (Betsa 1:3, 60c), at an old age R. Abahu would use two wooden slats on which he stood at the Tiberias bath-house. According to the story, he was bothered mainly by the cold, indicating that bath-houses with exposed floors were challenging mainly for old people and the frail, and were a source of agony.

Injuries to the Teeth

Tractate Derech Eretz, Perek ha-Nichnas, halakha 3 (Higger 1935, p. 303) presented the view whereby one should not converse while in the bath-house, or even inquire after the health of one's friend, "due to the danger":

No one must greet his friend in the bath-house proper, because it may be endanger life; and if someone has greeted him, he should remind the one who greets him that he is in a bath-house; but some say, He may return the greeting, for no danger is involved.

The two opinions in this source were divided as to whether conversation in the bath-house is considered dangerous or not, but the cause of the danger was not mentioned. Both sides, those in favor and those against, are supported by other texts. According to one source, it is desirable to open one's mouth while in the caldarium or the sweating room, as exhaling cools the bather's body (Sabbath 41a). In contrast, according to the tradition brought in the Jerusalem Talmud, Avoda Zara 3:4, 42d, exposing the teeth to the heat of the bath-house is harmful ("As the vapor of the bath-house is bad for the teeth").

\subsubsection{Mishaps and Accidents}

\section{"Burning by Fire"}

In the Talmud Jerusalem Talmud, Berakhot 9:4, 14b, fire topped the list of hazards mentioned in the bath-house prayer, which included the fire hazard, hot water, and finally collapse of the bath-house floor. This order is probably not random, rather it reflects the gravity of each hazard and its likelihood of occurring. As a rule, the bathers were not directly exposed to fire. The danger of being set on fire or burned by fire might have materialized in two instances: A. If the floor of the hot room collapsed and a person fell near the mouth of the furnace (see below); B. In case of a fire-fires were a fairly common occurrence in cities in the classical era, apparently as a result of crowded housing, use of flammable materials (wood), and the presence of an open fire in homes and in the streets, such as torches used for lighting, ovens, and braziers (Canter 1932). Rabbinical sources as well have many reports of fires, but the extent and implications of this phenomenon have not been studied (Mishnah Sabbath 16:2; Jerusalem Talmud, Yoma 8:4, 45b; Babylonian Talmud, Baba Kama 23a).

The baths were prone to fires due to two major factors. They housed furnaces with a continuously burning fire, and in large bath-houses the fire was intense. The bath-house contained large amounts of flammable materials that might have kept the fire going, particularly wood. According to rabbinical sources, the bath-house had a storeroom for wood to stoke the fire (beit ha-etzim = wood room), a storeroom for boards (beit ha-nesarin = boards room), probably to cover the hot floor, and also wooden benches for seating (Mishnah, Baba Batra 4:6; Babylonian Talmud, ibid., 67b-68a).

One source that best expresses the concern of fire at the bath-house is a Talmudic story about R. Yehuda Hanassi who lived and operated at the turn of the second century, and in another 
version about his student, the amora R. Yanai who operated in Eretz Israel. Every time he would enter a bath-house where a stoked furnace was used to heat the water or the floor he would "leave a last testament" for his household (metzave al beyto), in case he died while bathing (Jerusalem Talmud, Berakhot 4:4, 8b; Buber 1894, p. 96; Margalioth 1997, p. 730).

The Eretz Israel based amora R. Abahu of the third generation, who lived and operated in Caesarea and was himself saved from an accident at the bath-house (see below) claimed that deliverance from fire should be mentioned only in the case of a bath-house heated by a furnace, probably of a large permanent type that produces intense heat. If the bath-house is not heated by a furnace (or apparently also by small mobile heaters), however, the risk of fire should not be mentioned (Jerusalem Talmud, Berakhot, 9:4,14b). Abahu further adds that even in a bath-house that is not heated it is necessary to mention the danger of "hot water" (see below).

Dangers Associated with Water: "Hot Water Hazard" and "Water Sinking"

The meaning of the word hamin in the Mishna and Talmud literature is hot water (Mishnah Betsa 2:5; Tosefta, Miqvaot 7:1, Zuckermandel 1937, p. 659; Hulin 24b). Thus, heizek ha-hamin in the Jerusalem Talmud, Berakhot, 9:4, 14b refers to burns caused by very hot water. Ancient heating systems had no way of controlling the water temperature. The bath-house attendant, responsible for heating the water in the bath-house, could not regulate the temperature, and sometimes the water was too hot and may have caused burns.

The concern of "water sinking" is mentioned in Tractate Kala Rabati 9:13, Higger 1936, p. 337. This expression is fairly vague and was clarified by neither the traditional commentators nor the scholars. It may, in fact, be interpreted in two ways. One is submersion-drowning in the water, as a result of fainting or an unintentional blow by another bather (see below). Another possibility is the "sinking" of the water, i.e., flooding, as a result of damage to or breakage of the water pools or bath. In this case the bather might be harmed by the water, particularly when the basin is large and contains a significant amount of water.

\section{Collapse of the Caldarium's Floor}

Sometimes the bath-house held in store unexpected calamities. One was the mapolet or in other versions mapolet avanim (ben Sheshna 1971, p. 185), i.e., the collapse of the caldarium's or sweating room's floor into the hypocaust. Assuming that the order of the hazards mentioned in the Jerusalem Talmud reflects the frequency in which they occurred, the impression is that this was not a very common incident, rather on a moderately likely level of possibility. In many cases, the floor of the caldarium was supported by small pillars of stone or brick, densely laid, or on small brick arches, but sometimes these too were absent. The floor might have collapsed as the result of a heavy load caused by many bathers, but I do not know whether the number of people who could be in the caldarium at any given time was limited in any way.

The floor could collapse for another reason as well. The intense heat caused cracks and disintegration of the mortar. Yoram Tsafrir says that the floor was flooded with hot water to prevent it from falling apart, but often this was not enough (Tsafrir 1988, p. 106). The hypocaust was several dozen centimeters high, but even from this height a fall might have been critical. Falls due to collapse of the floor were also dangerous when occurring near the furnace, or when the floor slats caught fire as a result of contact with the furnace.

The concern of the caldarium's collapse is mentioned in several Talmudic sources. Babylonian Talmud, Pesachim 112b brings a tradition in the name of R. Yossi son of R. Yehuda that warns of various dangers, including the hazards of the bath-house. R. Yossi son of R. Yehuda bar Ila'i, a fifth generation tanna, addressed the warnings to one of his friends, R. Yehuda Hanassi (on their friendship see Margalioth 2000, vol. II, p. 214), who as we saw earlier was very concerned of the fire hazard: 
Three things did R. Jose son of R. Judah charge Rabbi. Do not go out alone at night, and do not stand naked in front of a lamp, and do not enter a new bath-house, lest it [the floor] split. How long [is it regarded as new]?

—Said R. Joshua b. Levi: For twelve months.

Rashi in his commentary on the Talmudic sugya (ibid.) claimed that bathers might fall into the water-filled hypocaust. He may have suggested this following the expression "water sinking" mentioned in Tractate Kala Rabati 9:13 (Higger 1936, p. 337). It seems more probable, in any case, that the greatest risk as a result of the floor's collapse was that of falling into the space in which hot air circulated and perhaps suffocating.

The following source emphasizes that the caldarium's floor had a greater risk of collapse in new bath-houses, as the mortar or the stones were not yet sufficiently solidified. The floor could be considered resistant to collapse only once the bath-house had been in operation for an entire year. A similar approach is mentioned in the sources with regard to furnaces as well. Baking ovens were normally made of clay and the furnace was only solidified after coming into contact with fire (Betsa 34a).

The Babylonian Talmud in Pesachim (ibid.) did not stop at providing warnings of dangers that might be encountered by bathers at the baths. The sugya tells the story of R. Abahu that gives an example of the caldarium floor's collapse:

R. Abbahu once went into the bath-house and the floor of the bath-house gave way beneath him, and a miracle was wrought for him, and he stood on a pillar and rescued a hundred and one men with one arm.

As stated above, R. Abahu lived and operated in Caesarea in the late third and early fourth century CE. The story of the collapse may have occurred at the baths in Caesarea. The description of the incident here is undoubtedly exaggerated. It may intend to glorify R. Abahu, but it more likely insinuates that the heavy weight of the many people present at the bath-house was a decisive factor in the floor's collapse. In this incident, R. Abahu was saved by standing on one of the pillars, which as stated were made of stone, a resistant material that does not easily disintegrate in heat, compared to the plaster floor.

\section{Danger of Injury from Glass Fragments}

Tractate Derech Eretz, Perek ha-Nichnas, halakha 2 (Higger 1935, p. 302) forbade bringing glass vessels containing oil to the public bath: "No one should bring oil in glass vessels to the bath-house, because that may endanger life". The reason of the prohibition was mentioned in Kala Rabati 9:15 (Higger 1936, p. 339): "What is the reason? Maybe the vessel will be broken and it will risk the people [in the bath-house]". Natural or scented oils were placed in small glass vessels and rubbed on the body or added to the water of the bathing basins (Tatton-Brown 1991, pp. 62-97). Other sources confirm the restriction of using only earthenware vessels in the bath-house. These vessels were indeed breakable, but their fragments were larger and could be collected if necessary (compare Sabbath 40b).

Risk of Slipping on Oils or Spittle

Another possible mishap at the bath-house was the risk of slipping. Certain parts of the bath-house were wet, such as the frigidarium and tepidarium, as they contained water basins used to rinse the body. The sources do not explicitly mention the risk of slipping on water at the bath-house. This risk was discussed in other contexts in the rabbinical halakhic literature, for instance with regard to tort law, and was certainly relevant in the bath-house (Mishnah, Baba Kama 3:2).

The hygienic and pleasurable activities performed in the bath-house included applying oils to the body, which sometimes dripped on the bath-house floor. This was usually done in the massage room (unctarium) after bathing (Nielsen 1990, vol. II, p. 161). The bather would apply to his body 
oil called in some sources olirin (Sperber 1998, p. 61-63), and remove it with strigil, a special scraper (Boardman 1971, pp. 136-37). In practice, the oil was not collected but rather spilled onto the floor, which consequently became slippery and dangerous.

The customary practice in Roman bath-houses was to apply the oil by pouring it on a katavlia, i.e., a marble tablet, or on the floor of the bath-house, and then rubbing the body against it by lying down and rolling (Tosefta, Sabbath 3:17, Lieberman 1955, p. 15). Tractate Derech Eretz, Perek ha-Nichnas, halakha 2 (Higger 1935, p. 300) brings an opinion that prohibits this custom:

On the marble floor of the bath-house, one must not exercise, have oneself rubbed, or have one's limbs massaged. Once Rabban Gamaliel, while in the bath-house, became weak. He was offered oil while on the marble floor, but refused to take it. R. Simeon the son of Gamaliel used to say, One who has is limbs massaged on the marble floor of the bath-house, is like an ass [ ... ] One must not spit in the bath-house, because that too may endanger life; nor should one ever spit, in front of another person.

The sages saw this way of applying oil as an improper custom as it deviates from the laws of modesty, and therefore voiced strong objection to it, likening it to a donkey that rubs its body against the walls (Lieberman 2000, p. 474). In order to give validity to the rejection of this behavioral norm, the source relates that although Raban Gamliel (1st century CE.) was frail and it would have been convenient for him to utilize the marble tablet he didn't do so. Julius Preuss claims that using the marble to rub the oil was appropriate for sick people as it demanded less effort (Preuss [1911] 2004, p. 538). It exposed one less to the danger of slipping as the person was in a prone position, but this practice might have caused subsequent bathers to slip. The Tosefta Trumot 10:11 Lieberman 1955, p. 162) forbade priests from placing oil received as truma on the marble tablet at the bath-house in order to rub it on themselves (lehit'agel) because the oil was then lost. Saul Lieberman explains that although the marble tablet does not absorb the oil and does not cause it to be lost, some oil remains that does not enter the priest's body. This oil could have caused not only a halakhic problem but also a risk of slipping (Lieberman 2000, Masekhet Trumot, p. 473).

As I have said, the risk of slipping on the oil was not stated explicitly, however this does seem to have been a concern in the case of spitting on the bath-house floor. Tractate Kala Rabati 9:17 (Higger 1936, p. 339) says: "And in any case, one shall not spit before his friend". It is clear that this law was brought in the context of the bath-house, as it is mentioned among the laws that deal with proper conduct in the bath-house. The redactor may have worded it in a general form because it is relevant for all public spaces, although it may be intended specifically for the bath-house, i.e., care must be taken to avoid spitting in all rooms of the bath-house. In fact, Kala Rabati does not mention the reason for the prohibition, although it is clear that spitting in a public space arouses disgust. Tractate Derech Eretz mentions the prohibition of spitting in any place and also the specific prohibition against spitting in the bath-house. This source states explicitly that spitting in the bath-house is forbidden "because it is dangerous", but the precise danger was not clarified. Some commentators claim that this had to do with the concern of slipping on the spittle, particularly in the case of a stone floor, and this interpretation certainly makes sense (Noymburg 1793, 41a).

\section{Hazardous Activities or Behavior}

Several sources relate to activities or behaviors that seem to have been customary in the bath-house and might have been hazardous. Tractate Kala Rabati 9:17 (Higger 1936, p. 339) says:

No one should lay his leg on the edge of the bath, and will jump into it, because this is a way of death [ ... ] One who immerses twice it is indeed disgraceful. Maybe he will crush people and will not see them.

A parallel Source is mentioned in Tractate Derech Eretz, Perek ha-Nichnas, halakha 4 (Higger 1935, pp. 303-4): 
No one should lie down in the bath, with his feet outstretched, and his face upward, for this is disgraceful; nor should one say to his friend in the bath-house, raise your hands on me (in Hebrew: רום ידך עלי. Higger, p. 114 suggested: Let us wrestle); if he does it, he will surely not leave the place without being hurt. R, Judah says, This rule regarding one's behavior in the bath, applies only when there is a little water in the bath; but if there is much water in the bath, such a practice is proper. It is not becoming one to read the "Shema" twice in succession, nor to use the bath twice in succession.

Many of these forbidden actions are mentioned in a few changes in the Tosefta Miqvaot 5:14 (Zuckermandel 1937, p. 657), and there is a room to examine in these cases the connection between the bath and the ritual bath:

One who jump to the ritual bath (mikveh) it is indeed disgraceful. One who immerses twice in the ritual bath it is indeed disgraceful. One who says to his friend in the bath-house press your hand on me (in Hebrew: עבוש ידך עלי) it is indeed disgraceful. R, Judah says,

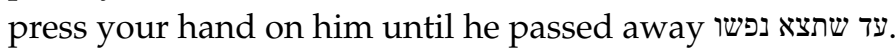

These forbidden actions were given different and varied interpretations with fairly vague meanings. Some understood them to be problematic for religious reasons, while others claimed that they were forbidden because they are hazardous. I shall discuss each of them, focusing primarily on the hazardous actions:

A. Sitting in the bath-this prohibition is mentioned only in Tractate Kala and is explained as derech gnai (improper conduct). It appears to have been a supine position perceived as immodest, and is unrelated to any hazard.

B-C. Standing on the edge of the bath and jumping in or immersing oneself twice-these two prohibitions are mentioned in association with the bath-house and in the context of the ritual bath. Some claim that this was a ritual bath that contained a small amount of water, and therefore if one jumped in the water would spray out and the immersion would take place in a ritual bath with insufficient water (Ben Jechiel 1886, siman 21, 94a). According to another interpretation, the religious problem was different-when a person jumps into the water or immerses himself twice, he does not seem to be performing a ritual immersion rather only cooling his body (Bar Sheshet Perfet 1878, siman 293). Nevertheless, these understandings do not explain the prohibition with regard to the bath-house. Perhaps it referred to a water basin within the bath-house that was used for purposes of ritual immersions (Grossberg 2001), but it is more likely that in both cases, that of the bath-house and that of the ritual bath, the problem was one of safety and not of halakha.

In Tractate Kala this is stated explicitly. Jumping into the water was defined as a conduct that might cause death (mita), i.e., the jumper might injure himself, but might also land on bathers who are already in the water. Saul Lieberman claimed that the prohibition against exercise in the bath-house, mentioned in Tractate Derech Eretz, Perek ha-Nichnas, halakha 2 (Higger 1935, p. 300) includes jumping into the water, and that double immersion was also an act of exercise in the water. Lieberman claims that the prohibition is because the bather is wet from the immersion and his sight is hampered, therefore the concern that if he does not dry himself after the first immersion he will inadvertently step on one of the bathers. Namely, this is a hazard-related prohibition (Lieberman 1939, pp. 54-58; 1991, pp. 118-22).

D. Strongly pressing one's hands against the person immersing himself in the bath-this prohibition is mentioned both in regard to the bath-house and in regard to ritual immersion. In ritual immersion, the water in the ritual bath is shallow and it is hard to immerse one's entire body. The bather has two options: to raise the level of the water by placing bundles of wood or canes or by having someone step on his body in the water to press it down and ensure complete immersion. In any case, this method is dangerous both when immersing in a ritual bath and when bathing in a bath-house 
with shallow water. R. Yehuda explains that the problem in the bath-house is specifically when the water is shallow, whereby strong pressure is applied. However when there is a large amount of water pressure is "commendable", as it is applied gently.

\section{Discussion}

In rabbinical times, several prayers and supplications were introduced for entering hazardous places or situations. In all these cases, one was obligated to ask for mercy when entering and to utter thanksgiving to God upon safely leaving. Beside the bath-house prayer, the sages also introduced five other prayers, which we shall describe in short:

A. A prayer before entering the polis (city-state), which was mostly populated by non-Jews and of a pagan nature (Mishnah Berakhot, 9:4; Tosefta, ibid., 6:16, Lieberman 1955, p. 37; 2000, p. 118). Rashi explained that the city contains evil governors who might harass and falsely accuse travelers (Berakhot 54a). However, judging by the sages' descriptions of the city as a place that poses residential challenges, the concern may have stemmed from the dense population and high living expenses, as well as the poor morals of its inhabitants (Babylonian Talmud, Eruvin 21b; Pesachim 113a; Ketubut 110b.

B. A prayer for journeys, recited in desolate areas outside the city, due to one's vulnerability to robbers and wild animals (Babylonian Talmud, Berakhot 29b).

C. A prayer recited in association with bloodletting (phlebotomy), considered a routine medical or hygienic practice. The complications, such as infections or losing large amounts of blood, could potentially cause patients health-related harm (Babylonian Talmud, Berakhot 60a).

D. A prayer before entering the lavatory-the lavatory was considered an unprotected place. It is described in Jewish sources as a place occupied by demons (Masekhet Kala 1:11, Higger 1936, p. 140; Babylonian Talmud, Kidushin 72a; Berakhot 62a; Gittin 70a; Baruch and Amar 2004), and snakes might also bite those who use it (Leviticus Rabba, 22:4, Margalioth 1953, pp. 505-6; Berakhot $62 \mathrm{~b})$. He who enters the lavatory takes leave of the angels that guard him during the day (Derech Eretz, Perek ha-Yotze, halakha 17, Higger 1935, pp. 318-19; Kala Rabbati 9:13, Higger 1936, p. 337). He remains alone with no supervision, menaced by demons and ghouls; this situation renders him vulnerable and it might be hazardous.

E. The bedtime prayer-when going to bed at night, a person is directed to recite the Hamapil blessing and the first section of the Shema. Sleep constitutes a transition from a state of wakefulness, functioning, and activity to one of passivity and lack of control. In ancient Jewish sources, sleep is perceived as a state of semi-death, from which there is no certainty that one will arise (Babylonian Talmud, Berakhot 57b; Genesis Rabba 17:5, Theodor and Hanoch 1903, pp. 156-57). Hence, a person going to sleep must pray that he will awaken, and upon awakening must give thanks that his or her soul returned to him and that he resumed his life and activities. Indeed, the wording of the blessing is "He who returns souls to dead bodies". (Marx 2005, pp. 250-89).

Religious traditions include manifestations of routine transitions in human life, such as the transition between day and night and the transition between weekdays and holidays. The situations mentioned above, including entering and leaving the bath-house, are routine transformative situations but they include an element of risk. The basis of all prayers for "entering" and "leaving" one domain for another is the sense of uncertainty, the anxiety and fears that arise as a result of the physical and conscious boundaries between life and death, illness and health, the divine role and the human role, and the internal and external parts of the human body.

According to Marx (2007), the theory of rites of passage, first proposed by French anthropologist Arnold van Gennep (1873-1957), can be used to understand the prayers mentioned here (Van Gennep 1960, pp. 189-90). First, it is necessary to stress that this theory is not fully compatible with prayers recited in situations of entering and leaving, as the latter do not concern dramatic 
processes in human life and are mostly extremely routine and private. Van Gennep's theory, in contrast, is usually applied to crisis transitions related to significant events in human life that generally occur in public, such as birth, adulthood, spousal relationships, and death.

Rites of passage are rituals practiced upon transition from one stage, situation, or status to another. Van Gennep identified three states that exist in all rites of passage. A. The first is leaving or departing an existing situation; B. An intermediate state is what Turner called the liminal stage, when the transition occurs (Turner 1969, pp. 94-96); C. The third stage is upon entering the new situation. In the liminal stage one is in the midst of the rite of transition and, in fact, is simultaneously in two opposite situations while also in neither of them. In the case of the bath-house, a person leaves the previous space from which he or she came (home, work, or other routine activities), but does not yet arrive at his destination, i.e., returning and continuing the normal life routine. In this unstable state, or as Turner says "betwixt and between", the bather will feel vulnerable and exposed and thus will seek special protection (Turner 1969, p. 95). The bath-house prayer raises awareness of the transition and also helps assuage the accompanying anxieties.

The various versions of the bath-house prayer further appear in post-Talmudic halakhic literature. The prayer is mentioned in several prominent compilations, for example, Rav Amram Gaon's prayer book (Babylonian, 9th century) (ben Sheshna 1971, p. 185); R. Simcha of Vitri's machzor (France 12th century) (Rabbi 1923, siman 529); the Mishneh Torah of Maimonides (Spain and Eygpt, 12th century) (Ben Maimon 1574, Mishneh Torah, Hilchot Berakhot 10:20); Sefer ha-Kolbo (Provance 13th-14th century) (Ha-Cohen 1997, siman 87); the Tur by Rabenu Yakov son of R. Asher (Spain 14th century) (Yakov and Asher 1861, Orach Haim siman 230), and R. Yosef Karo's Shulchan Arukh (Israel 16th century) (Karo 1993, Orach Haim siman 230, 3).

Following the transformation of the bath-houses and the transition to private bathing at home in the modern era, the bath-house prayer lost its relevance. R. Joel Sirkis (Poland 1561-1640), one of the greatest Ashkenazi adjudicators, referred in his commentary on the Tur to the transformation of the bath-house and its implications for the bath-house prayer:

At present, there is no custom to say Yehi Ratzon [=the bath-house pray] when entering the bath-house and it may have been a relevant regulation for their time only, as they would light a fire below, in the trench, and people would bathe in baths above the fire and there was a great danger [... ] But in our time when the furnace stands in its corner and the water is heated as houses are heated in the winter, there is no danger.

(Sirkis 1993, Orach Haim siman 230)

Sirkis explains that the custom of avoiding the bath-house prayer stems from the change in the furnace's location within the bath-house. While in the time of the sages the furnace was located under the floor on which the bathers stood and there was a concern of falling into the hypocaust, in 17th century European bath-houses the furnace was placed by one of the walls on the same level as the bathers. Hence, there was no danger of falling into the hot air or the fire.

In our times as well, when bathing is performed in personal baths with a hot water system that is not located in proximity to fire, the ancient bath-house prayer is no longer relevant. Admittedly, in modern settings accidents are possible, such as slipping, but it is clear that accidents associated with bathing have diminished considerably. Indeed, the bath-house prayer was left out of contemporary halakhic compilations.

Conflicts of Interest: The author declares no conflict of interest.

\section{References}

Author. 1523. Jerusalem Talmud. Venice: Daniel Bomberg. Simon, R. 1878. Yalkut Shimoni. Warsaw: Goldmam Press. Bar Sheshet Perfet, Itzhaq. 1878. Responsa Rivash. Vilna: Y. L. Metz. 
Baruch, Eyal, and Zohar Amar. 2004. The Latrine (Latrina) in the Land of Israel in the Roman-Byzantine Period. Jerusalem and Eretz-Israel 2: 27-50.

Ben Jechiel, Asher. 1886. Piskei ha-Rosh [=decisions of the Rosh]. In Babylonian Talmud. Vilna: Defus Re'em.

Ben Maimon, Moses. 1574. Mishneh Torah. Venice: Alwiso Bragad.

Ben Meir, Samuel. 1886. The Commentary of R. Samuel Ben Meir (Rashbam) on Baba Batra. In Babylonian Talmud. Vilna: Defus Re'em.

ben Sheshna, Amram Gaon. 1971. Seder Rav Amram Gaon. Edited by Daniel S. Goldschmidt. Jerusalem: Mossad ha-Rav Kook.

Boardman, John. 1971. Sickles and Strigils. The Journal of Hellenic Studies 91: 136-37. [CrossRef]

Bonner, Campbell. 1932. Demons of the Bath, Studies Presented to F.L. Griffith, EES. London: Oxford University Press.

Canter, H. V. 1932. Conflagrations in Ancient Rome. The Classical Journal 27: 270-88.

Carcopino, Jérôme. 1978. Daily Life in Ancient Rome. New Haven: Yale University Press.

Dunbabin, Katerine M. 1989. Balarium Grata Voluptas, Pleasures and Dangers of the Bath. PBSR 57: 36-39.

Eisenstein, Yehuda David. 1915. Otzar Midrashim. New York: Eisenstein.

Eliav, Yaron Zvi. 1995. Did the Jews at First Abstain from Using the Roman Bath-House? Cathedra 75: 3-35.

Eliav, Yaron Zvi. 2004. On the Idolatry in the Roman Bathhouse-Two Comments. Cathedra 110: 173-80.

Friedheim, Emanuel. 2002. The Story of Rabban Gamaliel in the Bath of Aphrodite in Acre: A Study of Eretz-Israel Realia in the 2nd and 3rd Centuries C.E. Cathedra 105: 7-23.

Gichon, Mordechai. 1978. Roman Bath-houses in Land of Israel. Kadmoniyot 11: 37-53. [PubMed]

Goor, Asaf. 1966. The History of the Grape-Wine in the Holy Land. Economic Botany 20: 46-64. [CrossRef]

Grimal, Pierre. 1983. Romam Cities. Wisconsin: The University of Wisconsin Press.

Grossberg, Asher. 2001. Ha-Metaeret sheba-Merchatz. Cathedra 99: 171-84.

Grossberg, Asher. 2007. The Miqva'ot (Ritual Baths) at Masada. In Masada VIII: The Yigael Yadin Excavations 1963-1965: Final Reports. Edited by Joseph Aviram, Gideon Forester and Ehud Netzer. Jerusalem: Israel Exploration Society, Jerusalem: The Hebrew University of Jerusalem.

Ha-Cohen, Aaron ben R. Jacob. 1997. Sefer ha-Kolbo. Jerusalem: Defus Abraham.

Hadar, Duby. 1995. Bathhouses in the Palestinian Society in the Period of the Mishnah and Talmud: Distribution and Social Function. Master's dissertation, Bar Ilan University, Ramat Gan, Israel.

Higger, Michael. 1935. Tractates Derech Eretz. New York: Deve Rabanan.

Higger, Michael. 1936. Tractates Kala: Tractate Kala and Tractate Kala Rabati. New York: Deve Rabanan.

Karo, Yosef. 1993. Shulchan Arukh. Jerusalem: Ketuvim.

Lieberman, Saul. 1939. From Aggadah to Halakha. Sinai 4: 54-58.

Lieberman, Saul. 1955. Tosefta. New York: Jewish Theological Seminary.

Lieberman, Saul. 1991. Researches on Torat Israel. Edited by David Rosenthal. Jerusalem: Magnes, The Hebrew University. Lieberman, Saul. 2000. Tosefta Ki-Fshuta. New York and Jerusalem: Jewish Theological Seminary Press.

Margalioth, Mordechai. 1953. Va-Yikra Rabba. Jerusalem: Misrad ha-Chinuch.

Margalioth, Mordechai. 1997. Midrash ha-Gadol of R. David ha-Adani. Jerusalem: Mossad ha-Rav Kook.

Margalioth, Mordechai. 2000. Encyclopedia of Talmudic and Geonic Literature. Tel Aviv: Yavne and Sifre Hemed.

Marx, Dalia. 2005. The Early Morning Ritual in Jewish Liturgy: Textual, Historical and Theological Discussion in Birkhot Hashakhar (The Morning Blessings) and an Examination of their Performative Aspects. Ph.D. Dissertation, Hebrew University, Jerusalem, Israel, August 29.

Marx, Dalia. 2007. 'ha-Nichnas la-Kerach': Prayers at the Entrance. Madaei ha-Yahadut 44: 105-36.

Nielsen, Inge. 1990. Thermae et Balnea: The Architecture and Cultural History of Roman Public Baths. Aarhus: Aarhus University Press.

Preuss, Julius. 2004. Biblisch Talmudische Medizin. (=Preuss, Julius. 2004. Biblical and Talmudic Medicine.); Translated by Fred Rosner. New York, Toronto and Oxford: Rowman \& Littlefield Publishers, Inc., First published 1911.

Rabinovitch, Raphael Nathan Neta. 1867. Dikdukei Sofrim. München: Ressel.

Reich, Ronny. 1988. The Hot Bath House ('Balneum'), the 'Miqweh' and the Jewish Community in the Second Temple Period. Journal of Jewish Studies 39: 102-7. [CrossRef]

Rabbi, Simcah. 1923. Machzor Vitri. Edited by Shimon ha-Levi Horovitz. Nirenberg: Itzhaq Bulka.

Smith, William, and Charles Anthon. 1843. A dictionary of Greek and Roman Antiquities. New York: Harper and Brothers. 
Sirkis, Yoel. 1993. Turim. Jerusalem: Makhon Jerusalem.

Sperber, Daniel. 1998. The City in Roman Palestine. Oxford: Oxford University Press.

Tatton-Brown, Veronica. 1991. The Roman Empire. In Five Thousand Years of Glass. Edited by Hugh Tait. London: British Museum Press.

Theodor, Julius, and Albeck Hanoch. 1903. Genesis Rababh. Berlin: Itzkowski.

Tsafrir, Yoram. 1988. Eretz Israel from the Destruction of the Second Temple to the Muslim Conquest, vol. II: Archaeology and Art. Jerusalem: Yad Itzhaq ben Zvi.

Turner, Victor. 1969. The Ritual Process: Structure and Anti-Structure. New York: Cornell University Press.

Van Gennep, Arnuld. 1960. The Rites of Passage. Chicago: University of Chicago Press.

Yakov, Rabenu, and son of R. Asher. 1861. Tur. Warsaw: Ergelbrand.

Zuckermandel, Moses Samuel. 1937. Tosefta. Jerusalem: Bamberger and Wahrmann.

(C) 2017 by the author. Licensee MDPI, Basel, Switzerland. This article is an open access article distributed under the terms and conditions of the Creative Commons Attribution (CC BY) license (http://creativecommons.org/licenses/by/4.0/). 